\section{INTERNATIONAL TRANSFERS OF COMBAT AIRCRAFT, 2005-2009}

\author{
SIEMON T. WEZEMAN
}

Combat aircraft dominate international arms transfers. They accounted for 27 per cent of the volume of transfers of major weapons over the period 2005-2009. This dominant position is even more apparent if all the weapons and components that are transferred for use with combat aircraft-missiles, bombs, sensors and engines-are taken into account. Together, combat aircraft and related weapons and components accounted for around 33 per cent of the volume of transfers (see figure 1 and box 1; see also box 2 below for an explanation of SIPRI estimates of volumes).

The fact that combat aircraft form such a large segment of transfers of major weapons is neither surprising nor dramatically new. However, with their potential for sudden and long-range attacks, combat aircraft are among the weapons with the greatest potential to cause instability. They are also expensive to acquire and to operate and thus place a heavy burden on military budgets. For these two reasons, transfers of combat aircraft have been and remain a matter of great importance and concern.

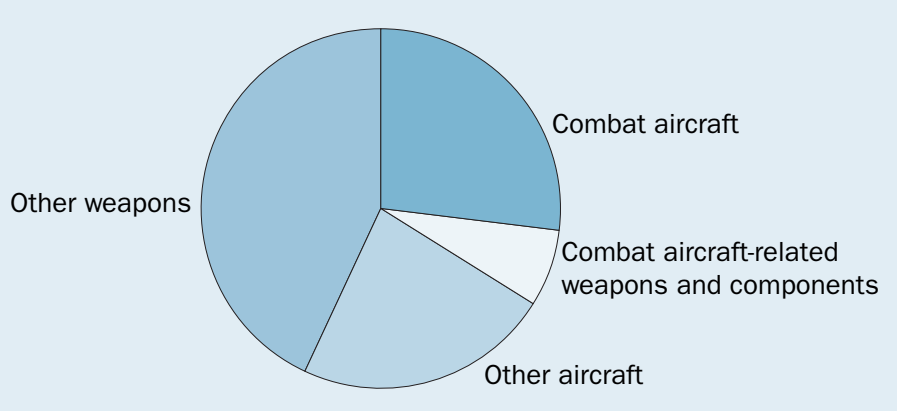

Figure 1. Combat aircraft as a share of the volume of international transfers of major conventional weapons, 2005-2009

Box 1. Defining combat aircraft

There is no internationally recognized definition of 'combat aircraft'. In this fact sheet they are defined as jet-engined aircraft primarily designed to engage in air-toair or air-to-ground combat. Table 1 lists the combat aircraft produced in 2005-2009.

This definition does not include the substantial number of smaller jet-engined trainer aircraft that often have a secondary or even primary combat role (such as the Chinese K-8 or the British Hawk), other light armed aircraft (such as the Brazilian EMB-314, the Swiss PC-7 and PC-9 or the US AC-208), anti-submarine warfare aircraft or armed helicopters.

\section{KEY FACTS}

- Combat aircraft accounted for 27 per cent of the volume of international transfers of major conventional weapons in 2005 2009.

- Weapons and components related to combat aircraft accounted for a further 7 per cent of transfers.

- Only 11 countries produce combat aircraft: China, France, Germany, India, Italy, Japan, Russia, Spain, Sweden, the United Kingdom and the United States.

- Russia and the USA are by far the two largest suppliers of combat aircraft.

- Second-hand aircraft accounted for 26 per cent of the combat aircraft transferred in 2005-2009.

- For arms-producing countries, sales of combat aircraft are often the highestvalued arms exports.

- Over the period 2005-2009, 44 countries imported combat aircraft.

- India, the United Arab Emirates and Israel-which each lies in a region of serious international tensions-were by far the largest importers of combat aircraft.

- Combat aircraft have the potential to be among the most destabilizing of weapons.

- The more advanced combat aircraft cost over $\$ 40$ million each. Even for rich countries, the acquisition of such expensive systems may shape the direction of defence policy and doctrine for many years. 
Table 1. Combat aircraft in production, 2005-2009

\begin{tabular}{|c|c|c|}
\hline Producer & Aircraft & Status in 2010 \\
\hline \multirow[t]{5}{*}{ China } & JF-17 & In production for export \\
\hline & JH-7 & In production for China \\
\hline & $\mathrm{J}-10$ & In production for China; first export order agreed \\
\hline & $\mathrm{J}-11$ & Unlicensed copy of Russian Su-27S; in production for China \\
\hline & F-7M & Outdated design offered to developing countries; in production for export \\
\hline \multirow[t]{2}{*}{ France } & Rafale & In production for France; offered for export but not yet ordered \\
\hline & Mirage-2000 & Production stopped 2007 \\
\hline India & Tejas (LCA) & Production for India started; no export orders \\
\hline Japan & $\mathrm{F}-2$ & Last in production for Japan; not offered for export \\
\hline \multirow[t]{4}{*}{ Russia } & $\mathrm{Su}-30 \mathrm{MK} / \mathrm{Su}-35$ & In production for Russia and export \\
\hline & $\mathrm{Su}-27 \mathrm{~S}$ & Probably no longer in production \\
\hline & MiG-29SMT/MiG-35 & In production for export; probably including production from parts in stock \\
\hline & $\mathrm{Su}-34$ & In production for Russia \\
\hline Sweden & JAS-39 & In production for export \\
\hline United Kingdom & Jaguar & Last in production under licence in India for India \\
\hline \multirow[t]{4}{*}{ United States } & $\mathrm{F}-15 \mathrm{E}$ & In production for export \\
\hline & F-16C & In production for export \\
\hline & F/A-18E & In production for USA and export \\
\hline & F-22 & Last in production for USA; not offered for export \\
\hline $\begin{array}{l}\text { Germany, Italy, Spain } \\
\text { and the UK }\end{array}$ & Typhoon (Eurofighter) & $\begin{array}{l}\text { In production for Germany, Italy, Spain and the UK and for export; } \\
\text { cooperative programme with exports handled by individual partners }\end{array}$ \\
\hline
\end{tabular}

Note: In addition, the F-35 Joint Strike Fighter is in the final testing and pre-production phase in the USA and the PAK FA is in the testing phase in Russia.

\section{THE SUPPLIERS OF COMBAT AIRCRAFT}

Only 11 countries currently produce combat aircraft: China, France, India, Japan, Russia, Sweden and the United States each produce locally designed aircraft, while Germany, Italy, Spain and the United Kingdom have formed a consortium for the production of the Eurofighter Typhoon (see table 1). A number of other countries also supply second-hand aircraft (see table 2).

Russia and the USA are by far the two largest suppliers of combat aircraft (and, indeed, of all major conventional weapons): combat aircraft accounted for about two-fifths of the volume of their total deliveries of major weapons in the period 2005-2009 (see table 3). Exports represent a substantial portion of these two countries' total production of combat aircraft and both the USA and Russia have received a constant stream of small and large foreign orders for combat aircraft in the past five years. The USA exported 331 new F-16C, F/A-18E and F-15E aircraft and produced a similar number of F/A-18E and F-22 aircraft for its own forces over the five years 2005-2009. Russia's exports of $215 \mathrm{Su}-25, \mathrm{Su}-27, \mathrm{Su}-30$ and MiG-29 aircraft outnumbered the aircraft produced for its own use by more than 10 to 1 . Based on known orders, this pattern will probably not change for the USA, while for Russia the proportion of aircraft produced for national use is likely to increase.

The pattern of exports of the smaller exporters of combat aircraft-China, France, Germany, Sweden and the UK-is uneven (see table 2). Production by these countries is often exclusively for national use as foreign orders are received infrequently. The other producers of combat aircraft-India, Italy, 
Table 2. Suppliers of combat aircraft, 2000-2004 and 2005-2009

Figures are the numbers of combat aircraft delivered by each supplier. Figures may not add up due to the conventions of rounding.

\begin{tabular}{|c|c|c|c|c|c|c|c|c|}
\hline \multirow[b]{2}{*}{ Supplier } & \multicolumn{2}{|c|}{ No. of new aircraft ${ }^{a}$} & \multicolumn{2}{|c|}{$\begin{array}{l}\text { No. of } \\
\text { second-hand aircraft }\end{array}$} & \multicolumn{2}{|c|}{ Total no. of aircraft } & \multicolumn{2}{|c|}{ Share of global total (\%) } \\
\hline & 2005-2009 & 2000-2004 & 2005-2009 & 2000-2004 & 2005-2009 & $2000-2004$ & 2005-2009 & 2000-2004 \\
\hline China & 41 & 76 & - & - & 41 & 76 & 4 & 8 \\
\hline France & 63 & 34 & 13 & 24 & 76 & 58 & 8 & 6 \\
\hline Germany & 15 & - & - & 14 & 15 & 14 & 1 & 1 \\
\hline Israel & - & - & 9 & 14 & 9 & 14 & 1 & 1 \\
\hline Russia & 215 & 287 & 4 & 44 & 219 & 331 & 22 & 35 \\
\hline Sweden & 37 & - & - & - & 37 & - & 4 & - \\
\hline Ukraine & - & - & 68 & 30 & 68 & 30 & 7 & 3 \\
\hline United Kingdom & 37 & 14 & - & - & 37 & 14 & 4 & 1 \\
\hline United States & 331 & 215 & 10 & 71 & 341 & 286 & 34 & 30 \\
\hline Others $^{b}$ & - & 13 & 152 & 102 & 152 & 115 & 15 & 12 \\
\hline Global total & 739 & 639 & 256 & 299 & 995 & 938 & 100 & 100 \\
\hline
\end{tabular}

${ }^{a}$ New aircraft include surplus (or second-hand) aircraft rebuilt to new status and aircraft already owned by recipients but rebuilt to new status by the supplier listed.

${ }^{b}$ Other suppliers include Belarus, Belgium, Bulgaria, the Czech Republic, Georgia, Jordan, Kyrgyzstan, Libya, the Netherlands, Poland, Singapore, Slovakia, South Africa, Spain, Switzerland and Venezuela.

Japan and Spain-receive orders (for both export and national use) infrequently and their ratios of production for export versus national use vary. In the period 2005-2009 some of these producers only produced for export, while others produced only for the national market.

China has exported about $41 \mathrm{~F}-7$ and JF-17 aircraft but has produced substantially more $\mathrm{J}-10, \mathrm{JH}-7$ and other combat aircraft for national use. While it has a substantial order for the JF-17 from Pakistan (reported as 50-150 units), there is no great prospect of large orders from other countries and production of the $\mathrm{J}-10$ and other combat aircraft for national use will continue to outnumber exports.

Table 3. Supplies of combat aircraft and related equipment as a share of all arms exports, 2005-2009

Figures are percentage shares of the total volume of exports of major conventional weapons of each supplier. Only producers of new weapons (aircraft or equipment) are included, but shares included exports of second-hand weapons.

\begin{tabular}{|c|c|c|c|c|c|}
\hline Supplier & Combat aircraft & $\begin{array}{l}\text { Missiles for } \\
\text { combat aircraft }\end{array}$ & $\begin{array}{l}\text { Sensors for } \\
\text { combat aircraft }\end{array}$ & $\begin{array}{l}\text { Engines for } \\
\text { combat aircraft }\end{array}$ & $\begin{array}{l}\text { Total combat } \\
\text { aircraft-related }\end{array}$ \\
\hline China & 18 & 1 & - & - & 19 \\
\hline France & 25 & 3 & - & - & 28 \\
\hline Germany & 7 & 1 & - & - & 8 \\
\hline Israel & 4 & 11 & 1 & - & 16 \\
\hline Italy & - & - & 4 & - & 4 \\
\hline Russia & 40 & 7 & - & 2 & 49 \\
\hline Sweden & 51 & - & - & - & 51 \\
\hline Ukraine & 23 & 20 & - & - & 43 \\
\hline United Kingdom & 18 & 16 & - & 3 & 37 \\
\hline United States & 39 & 6 & 2 & 1 & 48 \\
\hline Global total & 27 & 5 & 1 & 1 & 34 \\
\hline
\end{tabular}


Similarly, in 2005-2009 the producers of the Typhoon-Italy, Germany, Spain and the UK-made approximately 150 aircraft for national use and only 24 for export ( 15 from Germany and 9 from the UK). While Italy, Germany and Spain have no outstanding export orders, the UK as an individual Typhoon producer has about as many orders for export (c. 63 aircraft for Saudi Arabia) as for national use.

France, which had had outstanding orders for newly produced combat aircraft in every year since 1961, has had no deliveries outstanding since 2008. While France has historically produced more combat aircraft for export than national use, it exported only 17 newly produced Mirage-2000 aircraft in 2005-2009 compared with approximately 65 Rafales produced for national use. Despite aggressive marketing, it has not yet sold the Rafale abroad.

Sweden has produced a total of about 60 JAS-39 aircraft, of which 37 were exported in 2005-2009. It has no outstanding orders for national use and 25-31 are to be delivered to foreign buyers in the coming years.

Italy and Spain have not exported newly produced combat aircraft in recent years. India has never exported combat aircraft, while Japan does not offer combat aircraft (or other weapons) for export.

In addition to transfers of newly produced aircraft, second-hand combat aircraft have been transferred by both the original manufacturing countries and by other users. Second-hand aircraft accounted for 26 per cent of the number of combat aircraft transferred in 2005-2009 (see table 2). Ukraine, with a huge inventory of surplus Soviet-era aircraft, delivered the highest number of such second-hand aircraft in this period-68 aircraft, representing 27 per cent of the total number of second-hand aircraft transferred. After the USA, the original producer and largest user of F-16 aircraft, Belgium and the Netherlands were the largest exporters of F-16s; these states both sold aircraft that have become surplus due to reductions in the size of their armed forces.

For arms-producing countries, sales of combat

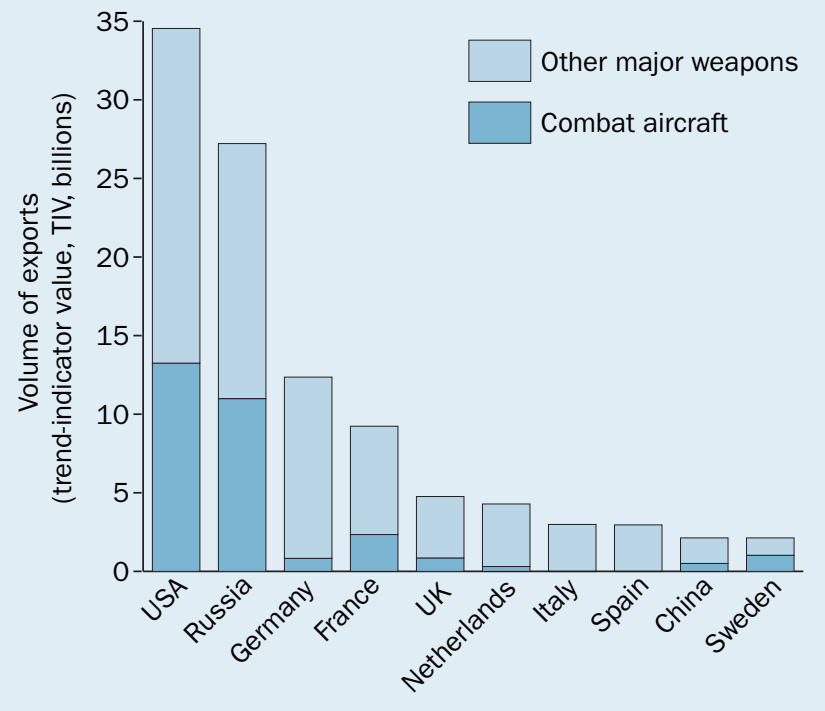

Figure 2. Exports of combat aircraft as a share of the total volume of exports of the 10 largest exporters of major conventional weapons, 2005-2009

Note: On the TIV see box 2. aircraft form a significant proportion of their arms exports (see figure 2) and are often the highestvalued arms exports. While all producers developed and continue to develop their combat aircraft for national use, they also see exports as almost a necessity in order to recoup some of the extremely high development costs. Governments of producer countries therefore often do their utmost to win orders for combat aircraft. This includes repeated visits by high-ranking government officials, including presidents and prime ministers, extensive offset arrangements, credits, technology transfers to local industries and fast deliveries from production originally earmarked for use by the exporter's own armed forces.

Because of the high values of combat aircraft programmes, it is not surprising that companies producing such aircraft or major components or weapons for them are consistently among the largest arms-producing companies in the world. In 
2007 and 2008, the three companies at the top of the SIPRI Top 100 arms-producing companies produced combat aircraft (among other weapons). Indeed, in both years, the 10 largest arms-producing companies either made combat aircraft or major components or weapons for them.

\section{THE RECIPIENTS OF COMBAT AIRCRAFT}

For most of the 10 largest importers of major weapons in the period 2005-2009, combat aircraft made up a substantial proportion of their arms imports (see figure 3).

Over the period 2005-2009, 44 countries imported combat aircraft (see table 4). India, the United Arab Emirates (UAE) and Israel were by far the largest recipients of combat aircraft. Together, these three countries-which each lies in a region of serious international tensions-accounted for

Table 4. Recipients of combat aircraft, 2005-2009

Figures are the numbers of combat aircraft delivered to each recipient. Figures may not add up due to the conventions of rounding.

\begin{tabular}{|c|c|c|c|c|}
\hline Recipient & No. of new aircraft ${ }^{a}$ & $\begin{array}{l}\text { No. of } \\
\text { second-hand aircraft }\end{array}$ & Total no. of aircraft & Share of total (\%) \\
\hline Algeria & 28 & 4 & 32 & 3 \\
\hline Austria & 15 & 4 & 19 & 2 \\
\hline Bangladesh & 16 & - & 16 & 2 \\
\hline Brazil & - & 25 & 25 & 3 \\
\hline Chile & 10 & 18 & 28 & 3 \\
\hline China & 45 & - & 45 & 5 \\
\hline Greece & 51 & - & 51 & 5 \\
\hline India & 115 & - & 115 & 12 \\
\hline Israel & 82 & - & 82 & 8 \\
\hline Jordan & - & 36 & 36 & 4 \\
\hline Korea, South & 40 & - & 40 & 4 \\
\hline Malaysia & 18 & - & 18 & 2 \\
\hline Pakistan & 23 & - & 23 & 2 \\
\hline Poland & 48 & - & 48 & 5 \\
\hline Singapore & 17 & - & 17 & 2 \\
\hline Syria & - & 33 & 33 & 3 \\
\hline United Arab Emirates & 108 & - & 108 & 11 \\
\hline United States & - & 31 & 31 & 3 \\
\hline Venezuela & 24 & - & 24 & 2 \\
\hline Yemen & 4 & 33 & 37 & 4 \\
\hline Others $^{b}$ & 95 & 72 & 167 & 17 \\
\hline Total & 739 & 256 & 995 & 100 \\
\hline
\end{tabular}

a New aircraft include surplus (or second-hand) aircraft rebuilt to new status and aircraft already owned by the recipient listed but rebuilt to new status by a supplier.

${ }^{b}$ Other recipients include Australia, Azerbaijan, Bangladesh, Chad, Colombia, the Czech Republic, Ecuador, Equatorial Guinea, Eritrea, Gabon, Georgia, Hungary, Indonesia, Iran, Mali, Namibia, Oman, Portugal, Saudi Arabia, South Africa, Sri Lanka, Sudan, Uganda and Viet Nam.

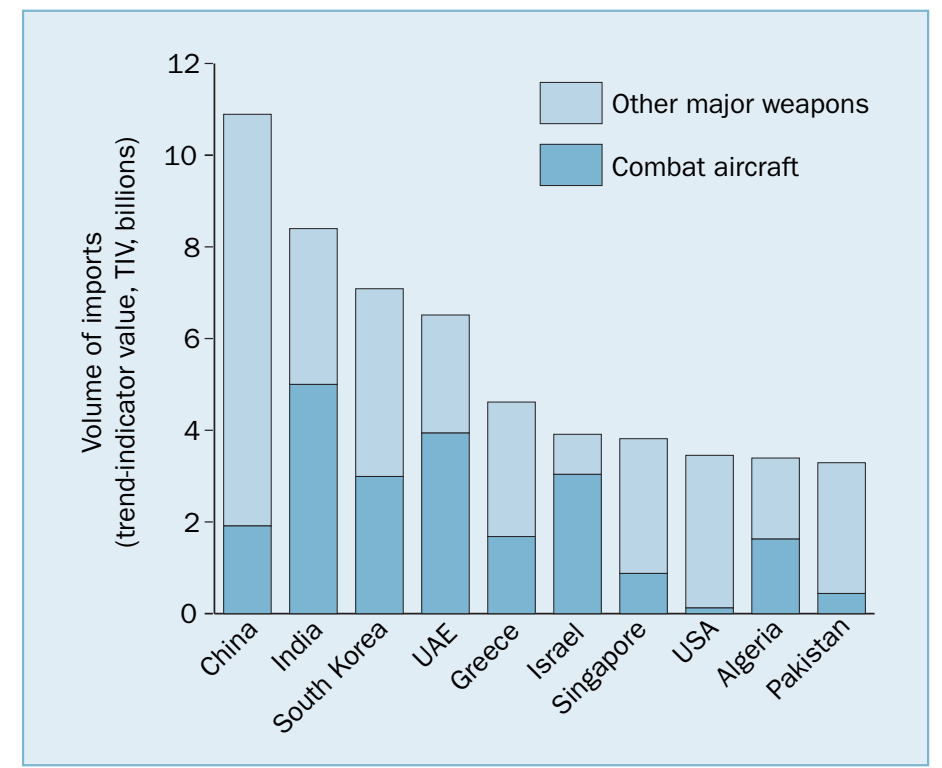

Figure 3. Imports of combat aircraft as a share of the total volume of imports of the 10 largest importers of major conventional weapons, 2005-2009

Note: On the TIV see box 2. 
almost one-third of all transfers of combat aircraft. For all three, combat aircraft made up far over half of the total volume of major arms imports for 2005-2009.

\section{THE IMPACT ON STABILITY}

Combat aircraft have the potential to be among the most destabilizing of weapons. While they are important as a defensive weapon, the possession of combat aircraft often also gives the capability to strike fast and far into neighbouring countries, as exemplified by the Israeli air attack on Syria in September 2007 and Russian attacks on Georgia in August 2008. This capability increases significantly when the aircraft are supported by tanker aircraft and when they are equipped with advanced electronic warfare systems and large numbers of short- and long-range stand-off precision weapons. Such weapons and systems have become the norm in recent years.

Because of their destabilizing potential, combat aircraft are specifically included among the weapons covered by the 1990 Treaty on Conventional Armed Forces in Europe (CFE Treaty). The European states that are party to the CFE Treaty must respect limits on their holdings of combat aircraft (as well as armoured vehicles, artillery, attack helicopters and tanks). In addition, all United Nations member states are expected to annually report their imports and exports of combat aircraft to the UN Register of Conventional Arms (UNROCA). UNROCA was established in 1991 to prevent the destabilizing build-up of arms. It includes seven categories of weapons considered potentially most destabilizing: armoured vehicles, artillery, attack helicopters, combat aircraft, missiles and missile launchers, tanks, and warships.

Seven of the eight states with nuclear weapons include combat aircraft among the systems for delivering these weapons (only the UK has abandoned aircraft as a means of delivery). Both India and Israel, two of the largest importers of combat aircraft, are known or believed to have assigned nuclear tasks to combat aircraft imported in recent years. However, while the transfer of ballistic and cruise missiles and their technology has been high on the arms control and export control agendas in part because of their

Box 2. The price of combat aircraft

The total price of combat aircraft acquisition programmes is a source of much confusion. Often, widely different prices are quoted in debates about acquisitions. For example, while Norway calculated a price of $\$ 54$ million for each F- 35 combat aircraft, at about the same time the US Department of Defense calculated a unit price of $\$ 97$ million. ${ }^{a}$

The reported values of, for example, recent orders for F-16s give unit values ranging from $\$ 60$ million to $\$ 100$ million (see table 5). Such large differences are partly related to the inclusion of more than aircraft in a contract but are also partly a reflection of a lack of transparency in how contracts are priced.

Because of this lack of data on prices and because prices do not necessarily reflect the value of a weapon as a military tool, SIPRI data on arms transfers uses a trend-indicator value (TIV) to compare data on deliveries of different weapons and to identify general trends in actual deliveries. TIVs give an indication of the volume of arms transfers and not the actual financial values of such transfers. ${ }^{b}$

${ }^{a}$ Cowan, G., 'Taking flight', Jane's Defence Weekly, 16 Sep. 2009, p. 27.

${ }^{b}$ For descriptions of the TIV and its calculation and use in the SIPRI Arms Transfers Database, see <http://www.sipri.org/ databases/armstransfers/background>. 
capability to carry nuclear and other mass destruction weapons, the transfer of advanced combat aircraft and air-to-ground missiles capable of carrying nuclear warheads is not.

\section{THE ECONOMIC IMPACT}

Combat aircraft are expensive pieces of military hardware: the more advanced aircraft cost over $\$ 40$ million each and often substantially more (see box 2 and table 5). Acquisition programmes for combat aircraft are the most expensive military hardware programmes for many countries.

The cost of the acquisition programmes is further heightened because other high-value contracts-for armaments, training, spare parts, maintenance and technical support, or infrastructure-are often signed simultaneously. In addition, operating costs are high and significant costs result from major upgrade programmes (e.g. midlife upgrades) that many combat aircraft undergo after having been in service for 15-20 years (see table 6 for examples).

Because of their high costs, combat aircraft can weigh heavily on military budgets. Even for rich countries, the acquisition of such expensive systems may shape the direction of defence policy and doctrine for many years-once bought, countries are unlikely to dispose of such high-value assets quickly.

Table 5. Selected orders for combat aircraft, 2005-2009

Values of orders or agreements are as reported by buyers, sellers or the media and may include more than just the aircraft.

\begin{tabular}{llll}
\hline Recipient & Supplier & Aircraft & Deal value (US\$ b.) \\
\hline Australia & United States & 24 F/A-18E & $4.8^{a}$ \\
India & Russia & 40 Su-30MKI & $1.5-1.6$ \\
Korea, South & United States & 21 F-15K & $2.3^{a}$ \\
Morocco & United States & 24 F-16C Block-50 & $2.4^{a}$ \\
Pakistan & United States & 18 F-16C Block-50 & 1.5 \\
Saudi Arabia & United Kingdom & 72 Eurofighter Typoon & $6.0-7.0$ \\
Singapore & United States & 12 F-15E & 1.0 \\
Thailand & Sweden & 6 JAS-39 & 0.49 \\
Turkey & United States & 30 F-16C Block-50 & 1.8 \\
Viet Nam & Russia & 8 Su-30MKK & $0.4-0.5$ \\
\hline
\end{tabular}

${ }^{a}$ The values of these orders include substantial amounts of weapons or support in addition to aircraft.

Table 6. Selected contracts for combat aircraft modernization, 2005-2009

Values of orders or agreements are as reported by buyers, sellers or the media. Values may include more than just the aircraft.

\begin{tabular}{|c|c|c|c|c|}
\hline Recipient & Supplier & Order year & Aircraft & Comments \\
\hline Colombia & Israel & 2007 & Kfir C-7 & $\begin{array}{l}\text { Modernization of } 12 \mathrm{Kfir} \text { C-7s as Kfir C-10s; part of a } \\
\$ 160 \text { million deal including } 13 \text { ex-Israeli Kfirs }\end{array}$ \\
\hline India & France & 2009 & Mirage-2000 & $\begin{array}{l}€ 1 \text { billion for rebuilding } 51 \text { Mirage-2000s as Mirage- } \\
2000-5 \mathrm{~s}\end{array}$ \\
\hline India & Russia & 2008 & MiG-29 & $\begin{array}{l}\$ 850-964 \text { million for rebuilding } 63 \mathrm{MiG}-29 \text { s as } \\
\text { MiG-29SMTs }\end{array}$ \\
\hline Pakistan & United States & 2008 & F-16A & $\begin{array}{l}\$ 891 \text { million modernization of } 32 \mathrm{~F}-16 \mathrm{As} \text { as F-16C } \\
\text { Block-50s }\end{array}$ \\
\hline Peru & Russia & 2008 & MiG-29C & $\$ 106$ million for modernization of $8 \mathrm{MiG}-29 \mathrm{Cs}$ as \\
\hline Saudi Arabia & United Kingdom & 2007 & Tornado IDS & $\begin{array}{l}\text { MiG-29SMTs and overhaul of } 19 \mathrm{MiG}-29 \mathrm{Cs} \\
\$ 1 \text { billion for modernization of } c .84 \text { Tornado IDSs to } \\
\text { Tornado GR-4s }\end{array}$ \\
\hline Saudi Arabia & United States & 2006 & F-15 & $\$ 1.5$ billion for new engines for $c .70 \mathrm{~F}-15 \mathrm{~S}$ \\
\hline Turkey & United States & 2006 & $\mathrm{~F}-16 \mathrm{C}$ & $\begin{array}{l}\$ 1.1 \text { billion for modernization of } 80 \mathrm{~F}-16 \mathrm{Cs} \text { with new } \\
\text { radar and combat system and } 37 \mathrm{~F}-16 \mathrm{Cs} \text { with smaller } \\
\text { modifications }\end{array}$ \\
\hline
\end{tabular}


SIPRI is an independent international institute dedicated to research into conflict, armaments, arms control and disarmament. Established in 1966, SIPRI provides data, analysis and recommendations, based on open sources, to policymakers, researchers, media and the interested public.

\section{GOVERNING BOARD}

Göran Lennmarker, Chairman (Sweden)

Dr Dewi Fortuna Anwar

(Indonesia)

Dr Alexei G. Arbatov (Russia)

Ambassador Lakhdar Brahimi (Algeria)

Jayantha Dhanapala

(Sri Lanka)

Dr Nabil Elaraby (Egypt)

Ambassador Wolfgang

Ischinger (Germany)

Professor Mary Kaldor

(United Kingdom)

The Director

\section{DIRECTOR}

Dr Bates Gill (United States)

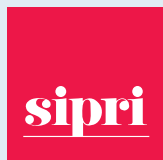

STOCKHOLM INTERNATIONAL PEACE RESEARCH INSTITUTE

Signalistgatan 9

SE-169 70 Solna, Sweden

Telephone: +4686559700

Fax: +4686559733

Email: sipri@sipri.org

Internet: www.sipri.org

\section{THE SIPRI ARMS TRANSFERS DATABASE}

The data included in this fact sheet is taken from the SIPRI Arms Transfers Database. The database contains information on all transfers of major conventional weapons from 1950 to 2009.

SIPRI data on transfers of major weapons are based on actual deliveries of major conventional weapons defined by SIPRI as: aircraft, armoured vehicles, ships over 100 tonnes, guided weapons, larger radars and other sensors, artillery over 100-mm calibre, missile and gun air-defence systems, and engines and turrets for selected larger platforms.

The infomation in the database is collected from a wide variety of sources: newspapers and other periodicals; annual reference books; monographs; official national and international documents; information from industry; and blogs and other Internet publications. The common criterion for all these sources is that they are open, that is, published and available to the public.

The SIPRI Arms Transfers Database is available online at <http://www.sipri.org/ databases/armstransfers/>.

\section{OTHER SIPRI SOURCES OF INFORMATION ON COMBAT AIRCRAFT}

\section{The SIPRI Top 100 arms-producing companies}

Information on the 100 largest arms-companies worldwide (excluding China) is published each year in the SIPRI Yearbook. The most recent list, for 2008, is available at <http://www.sipri.org/research/armaments/production/Top100/> and is discussed in Jackson, S. T., 'Arms production', SIPRI Yearbook 2010: Armaments, Disarmament and International Security (Oxford University Press: Oxford, 2010).

\section{World nuclear forces}

Information on the use of combat aircraft in the delivery of nuclear weapons appears in each edition of the SIPRI Yearbook. For the most recent information, see

Kile, S. N. et al., 'World nuclear forces', SIPRI Yearbook 2010: Armaments, Disarmament and International Security (Oxford University Press: Oxford, 2010).

\section{ABOUT THE AUTHOR}

Siemon T. Wezeman (the Netherlands) is a Senior Fellow with the SIPRI Arms Transfers Programme, where he has worked since 1992. Among his publications are several relating to international transparency in arms transfers, The Future of the United Nations Register of Conventional Arms, SIPRI Policy Paper no. 4 (August 2003), and Cluster Weapons: Necessity or Convenience? (Pax Christi Netherlands, 2005, co-author). He has contributed to the SIPRI Yearbook since 1993. 